a central catalogue of all printed matter on Africa to be found in the main libraries of Poland and over 12,000 bibliographical index cards have already been completed. A documentation service records the progress of African research in Poland.

\title{
University of Münster at Dortmund: Social Research Centre
}

A NEw section to study the sociology of the developing countries was added to the Social Research Centre in 1962 under the direction of Professor Dr. H. K. Pfeffer and Dr. HannsAlbert Steger. The purpose of the section is to carry out its own research projects and to co-operate in the work of social research with the other sections of the Centre. It also provides a basis for the sociological courses on the developing countries given at the University of Münster. Current researches include a study of social rise and industrialization in Zambia, by Dr. Lars Clausen.

\section{Association des Professeurs des Facultés de Droit et des Sciences Economiques pour le Développement et la Coopération}

L'Association a été créée en 1964 à Paris. Elle groupe actuellement plus de I 5 o universitaires francophones, la plupart en fonction hors d'Europe, et se propose de les aider à coordonner leurs recherches et résoudre certains problèmes de leur enseignement, obtenir un statut favorisant leur recrutement et leur action, préparer leur relève en pays étranger par des enseignants d'origine locale.

Pour tout renseignement s'adresser au Secrétaire-Général, Professeur Michel Alliot, 23 quai A. Le Gallo, Boulogne-sur-Seine (Seine).

\section{Field Research in Tanzania}

Professor Hugo Huber of Fribourg University has been engaged on a five-months field study on some aspects of the social organization (including marriage and dowry) of the formerly matrilineal Kwaya of Northern Tanzania. This project will be continued in March 1966. It is sponsored by the Swiss National Foundation for Scientific Research, together with a concurrent study by Otto Bischofberger, on age grade ceremonies among the neighbouring Zanaki. These form part of a larger research programme.

\section{Anthropological field-2work among the Embu of Kenya}

Professor Satish C. Saberwal of the University of Alberta, Canada, carried out field research among the Embu of Kenya from January 1963 to August 1964 , when he studied changes brought about in the socio-political system by colonial administration, coffee cultivation, the Mau Mau emergency, and basic changes in land tenure. Comparisons were made with parallel studies in land consolidation in Kikuyuland, and detailed transcripts were taken of court proceedings of litigation concerning problems of marriage and bridewealth. The concluding phase of the field-work consisted of interviews for the Donald CampbellRobert LeVine cross-cultural study of ethnocentrism, data from which may also be used in the preparation of a case study of traditional inter-tribal relations.

A reconstruction of the present pre-contact Embu socio-political system will shortly be available (Social Control and Cultural Flexibility among the Embu of Kenya, ca. 1900, University Microfilms, Ann Arbor, Michigan, early 1966), and a paper on the post-contact institutional transformation is in course of preparation. A further field trip, to be focused on contemporary Embu society, is provisionally planned for May-September 1966. 